\title{
Effects of Multikinase inhibitors on pressure overload-induced right ventricular remodelling
}

\author{
Baktybek Kojonazarov ${ }^{1 *}$, Akylbek Sydykov¹, Soni Savai Pullamsetti ${ }^{1,2}$, Himal Luitel', Bhola K Dahal ${ }^{1}$,

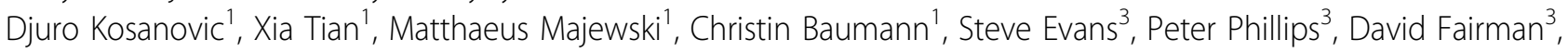 \\ Neil Davie ${ }^{3}$, Chris Wayman ${ }^{3}$, lain Kilty ${ }^{3}$, Norbert Weissmann ${ }^{1}$, Friedrich Grimminger ${ }^{1}$, Werner Seeger ${ }^{1,2}$, \\ Hossein Ardeschir Ghofrani ${ }^{1}$, Ralph Theo Schermuly ${ }^{1}$
}

From 2nd Cross Company Respiratory Symposium

Horsham, UK. 6-7 September 2012

Little is known about the effects of current PAH therapies and receptor tyrosine kinase inhibitors on heart remodelling. We sought to investigate the effects of the multikinase inhibitors sunitinib (PDGFR-, VEGFR- and KIT-inhibitor) and sorafenib (raf1/b-, VEGFR-, PDGFR-inhibitor) on pressure overload induced right ventricular (RV) remodelling. We investigated the effects of the kinase inhibitors on hemodynamics and remodelling in rats subjected either to monocrotaline (MCT)-induced $\mathrm{PH}$ or to surgical pulmonary artery banding (PAB). MCT rats were treated from day 21 to 35 with either vehicle, sunitinib $(1 \mathrm{mg} / \mathrm{kg}, 5 \mathrm{mg} / \mathrm{kg}$ and $10 \mathrm{mg} / \mathrm{kg} /$ day) or sorafenib $(10 \mathrm{mg} / \mathrm{kg} /$ day $)$. PAB rats were treated with vehicle, sunitinib $(10 \mathrm{mg} / \mathrm{kg} /$ day $)$ or sorafenib $(10 \mathrm{mg} / \mathrm{kg} /$ day) from day 7 to 21 . RV function and remodelling were determined using echocardiography, invasive hemodynamic measurement and histomorphometry. Treatment with both sorafenib and sunitinib decreased right ventricular systolic pressure, pulmonary vascular remodelling, RV hypertrophy and fibrosis in MCT rats. This was associated with an improvement of RV function. Importantly, after $\mathrm{PAB}$, both compounds reversed RV chamber and cellular hypertrophy, reduced RV interstitial and perivascular fibrosis, and improved RV function. We demonstrated that sunitinib and sorafenib reversed RV remodelling and significantly improved RV function measured via a range of invasive and non-invasive cardiopulmonary endpoints in experimental models of RV hypertrophy.

\section{Authors' details}

'Universities of Giessen and Marburg Lung Centre (UGMLC), Giessen, Germany. ${ }^{2}$ Department of Lung Development and Remodelling, Max-Planck Institute for Heart and Lung Research, Bad Nauheim, Germany. ${ }^{3}$ Inflammation and Remodeling Research, Pfizer Cambridge Massachusetts, 02140, USA.

Published: 14 August 2013

doi:10.1186/1476-9255-10-S1-P37

Cite this article as: Kojonazarov et al:: Effects of Multikinase inhibitors on pressure overload-induced right ventricular remodelling. Journal of Inflammation 2013 10(Suppl 1):P37.
Submit your next manuscript to BioMed Central and take full advantage of:

- Convenient online submission

- Thorough peer review

- No space constraints or color figure charges

- Immediate publication on acceptance

- Inclusion in PubMed, CAS, Scopus and Google Scholar

- Research which is freely available for redistribution
() Biomed Central

\section{() Biomed Central}

